\title{
Data analysis and modeling to support policy decisions in environmental, transportation, and energy systems
}

\author{
Zachary A. Collier $^{1} \cdot$ James H. Lambert $^{1} \cdot$ Igor Linkov $^{2}$
}

Published online: 9 November 2016

(c) Springer Science+Business Media New York 2016

This issue of Environment Systems \& Decisions, our sixteenth published issue, marks the milestone of our fourth year of publication. In these 4 years, over 2000 pages of high-quality research have been published on a variety of topics including energy, environment, transportation, nanotechnology, human health, climate change, and cyber security, covering academic disciplines such as decision analysis, systems engineering, risk analysis, ecology, public policy, economics, finance, data science, and psychology. This issue covers much of the same topics-application domains in this issue range from modeling of climate and transportation systems to discussions on science diplomacy and participatory decision-making tools. In particular, many of the papers in this issue focus on using data and modeling techniques to inform policy decisions such as large-scale vehicle fleet management, site selection of landfill facilities, or interventions to reduce the adverse impacts of heat waves in urban environments.

The issue opens with a perspectives article by Linkov et al. (2016) examining the intersection of scientific research and international diplomacy. The article explores the benefits and methods for international collaboration between the scientific and diplomatic communities, spurred by the experiences of several of the coauthors. Azmi and Tokai (2016) described a model built to assess the carbon dioxide emissions and other pollutants produced from

Igor Linkov

Igor.Linkov@usace.army.mil

Zachary A. Collier

zac4nf@virginia.edu

University of Virginia, Charlottesville, VA, USA

2 US Army Engineer Research \& Development Center, Concord, MA, USA
Malaysia's passenger vehicles. The authors use these estimates to compare fleet management policies in terms of greenhouse gas reductions. Next, Hanine et al. (2016) developed a decision model for selecting landfill sites based on political, environmental, economic, and social factors, using fuzzy multicriteria methods. Combining statistical and geospatial analysis, MacNee and Tokai (2016) identified the main sources of vulnerability to heat waves using principle component analysis and constructed a weighted heat wave vulnerability index based on these results. This index was mapped onto the districts of Osaka City, Japan, using geospatial tools. Singh (2016) performed a series of surveys from aviation experts to identify perceptions of greenhouse gas emission reduction for air transportation. Using structural equation modeling, it was found that aircraft technology and design as well as aviation operations held the largest potential for emission reductions. Skalski et al. (2016) described the regulatory testing requirements for various fish species, where certain amounts of fish passing through dams must survive. A set of criteria is proposed in which to assess the quality of these survival compliance tests. Finally, Masuhara et al. (2016) compared and contrasted elements of participatory decision-making methods across twenty-five case studies in Japan concerning environmental, energy, and food policy decisions.

Upcoming special issues of Environment Systems \& Decisions include proceedings from the 2016 International Symposium on Sustainable Systems and Technology (ISSST) edited by Editorial Board member Dr. Thomas Seager, and a special issue highlighting the research of current and recent students, edited by Editorial Board members Dr. Robyn Wilson and Dr. Joe Arvai.

Additionally, there will be an Editorial Board meeting held in December at the Society for Risk Analysis Annual 
Meeting in San Diego, CA, where attendees will review journal status and progress and discuss plans for the upcoming year.

\section{References}

Azmi M, Tokai A (2016) System dynamic modeling of $\mathrm{CO}_{2}$ emissions and pollutants from passenger cars in Malaysia, 2040. Environ Syst Decis. doi:10.1007/s10669-016-9612-7

Hanine M, Boutkhoum O, El Maknissi A, Tikniouine A, Agouti T (2016) Decision making under uncertainty using PEES-fuzzy AHP-fuzzy TOPSIS methodology for landfill location selection. Environ Syst Decis. doi:10.1007/s10669-016-9609-2

Linkov I, Basu S, Fisher C, Jackson N, Jones AC, Kuklja MM, Trump BD (2016) Diplomacy for science: strategies to promote international collaboration. Environ Syst Decis. doi:10.1007/ s10669-016-9614-5

MacNee RGD, Tokai A (2016) Heat wave vulnerability and exposure mapping for Osaka City, Japan. Environ Syst Decis. doi:10. 1007/s10669-016-9607-4

Masuhara N, Baba K, Tokai A (2016) Clarifying relationships between participatory approaches, issues, processes, and results, through crosscutting case analysis in Japan's environmental, energy, and food policy areas. Environ Syst Decis. doi:10.1007/ s10669-016-9613-6

Singh V (2016) Perceptions of emission reduction potential in air transport: a structural equation modeling approach. Environ Syst Decis. doi:10.1007/s10669-016-9608-3

Skalski JR, Weiland MA, Ploskey GR, Woodley CM, Eppard MB, Johnson GE, Carlson TJ, Townsend RL (2016) Establishing and using study criteria to ensure the rigor and robustness of survival compliance testing at hydroelectric dams. Environ Syst Decis. doi:10.1007/s10669-016-9615-4 